Natural History

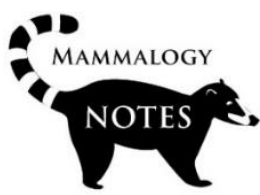

\title{
Accidental capture of the arboreal rodent Rhipidomys cf. macrurus in a mist-net in Silvânia National Forest, Brazil
}

\author{
Marcelino Benvindo-Souza* id , Acácio Arlem TomaziD, Daiany Folador Sotero1(iD, \\ Daniela de Melo e Silva' (i), Wellington Hannibal² (iD \\ 1 Laboratório de Mutagênese, Departamento de Genética. Instituto de Ciências Biológicas. Universidade Federal de Goiás. \\ CEP: 74690900, Goiania, Goiás, Brazil. \\ 2 Laboratório de Ecologia e Biogeografia de Mamíferos, Universidade Estadual de Goiás. CEP 75860-000, Quirinópolis, Goiás, \\ Brazil. \\ * Correspondence: marcelinobenvindo@gmail.com
}

\section{Resumen}

Describimos un evento de captura incidental de un individuo de Rhipidomys cf. macrurus en una red de niebla durante muestreo de quirópteros realizado en la Unidad de Conservación del Bosque Nacional Silvânia, municipio de Silvânia, Goiás, Brasil. La captura de animales que no sean aves y murciélagos en redes de niebla es excepcional, por lo que nuestro registro es uno de los pocos reportados en la literatura que involucra a un roedor. Suponemos que el individuo se enredó mientras buscaba alimento en la vegetación que rodeaba la red.

Palabras clave: FLONA-Silvânia, monitoreo, red de niebla, murciélagos, rata.

\section{Abstract}

We describe a bycatch event of an individual of Rhipidomys cf. macrurus in a mist-net during a chiroptera survey carried out in the Conservation Unit Silvânia National Forest, Silvânia municipality, Goiás, Brazil. Catching animals other than birds and bats in mist-nets is exceptional, so our record is one of the few reported in the literature and involving a rodent. Presumable the individual became entangled while foraging in the vegetation surrounding the mis-net.

Key words: FLONA-Silvânia, monitoring, mist net, bats, rat.

Mist-nets have been one of the primary methods for capturing birds (Gosler 2004) and bats (Garcia 1998) due to the fineness of the nylon threads that compose them, which are practically undetectable by eye (Peracchi \& Nogueira 2010). Its invention is attributed to Japanese hunters (Low 1957); however, its scientific purpose in the West only came about in the first half of the last century (Peracchi \& Nogueira 2010). And so far, only a few studies have reported accidental captures of animals other than birds or bats with these devices 
(Sykes 1989, Fernandez \& Amarga 2020). In this context, here we report by the first time the capture of a rodent (Rhipidomys cf. macrurus) in a mist-net during a bat survey in Brazil.

The event was noticed on December 8 th, at $8: 30 \mathrm{pm}$ during a routine inspection of a mist net installed in a fragment of semi-deciduous forest ( $16^{\circ} 38^{\prime} 25.29^{\prime \prime} \mathrm{S} ; 4^{\circ} 38^{\prime} 57.24^{\prime \prime} \mathrm{W}$ ) at the Silvânia National Forest Conservation Unit (FLONA-Silvânia), Silvânia, Goiás, Brazil. The Park has an area of 486.37 ha (MMA 2021), exhibiting almost all types of Cerrado vegetation, but mainly savannas and typical forests (Araújo et al. 2012; Bergamini et al. 2017). The rodent was removed from the mist-net, weighed $(64 \mathrm{~g})$, and released in the same capture area (Figure 1). Although we don't know exactly how accidental capture occurred, we hypothesize that the rodent was trying to catch some arthropods that previously had become entangled in the mist-net. However, we do not discard that the rodent ended up in the net while moving through the surrounding vegetation.
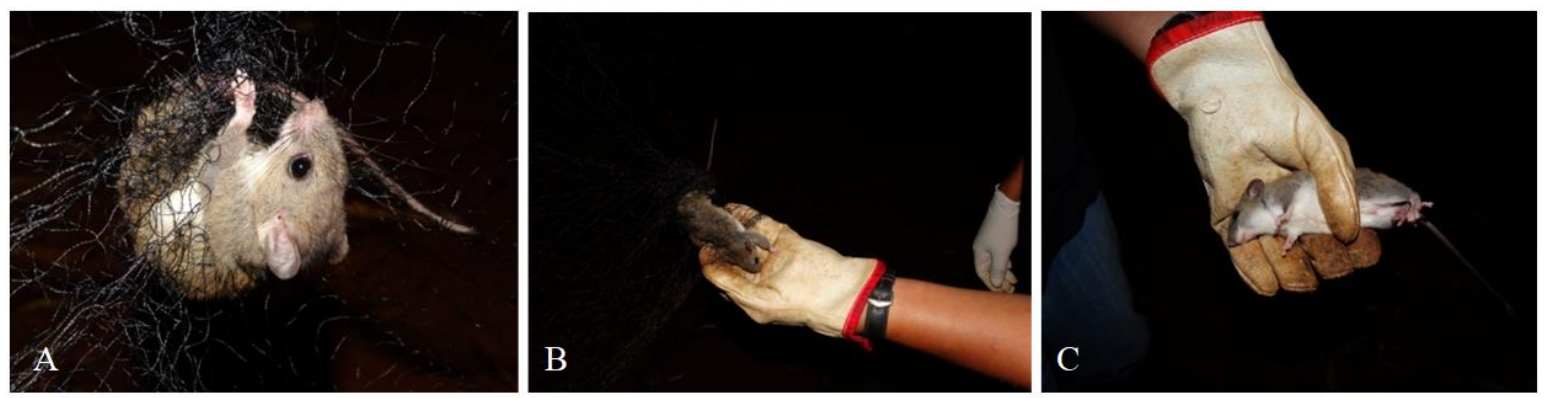

FIGURA 1. Individual of Rhipidomys cf. macrurus in a mist-net. A) Captured animal, B) Removing the animal, and C) Animal after being removed from the net.

Rhipidomys macrurus is an arboreal rodent with a body mass between 40 and $130 \mathrm{~g}$, inhabiting forest formations (e.g., gallery forest, woodland savanna, and semi-deciduous forest) from the Cerrado domain in Brazil, occurring in the states of Maranhão, West of Piauí, north of Ceará, east of Bahia, east of Minas Gerais, Tocantins, Goiás, Federal District and southwest of Mato Grosso (Bonvicino et al. 2008, Paglia et al. 2012, Tribe 2015). R. macrurus was one of the most abundant rodent species in fragments of semi-deciduous forest in southern Goiás, and in this highly fragmented landscape ( 13\% native vegetation cover), the species is associated with a high canopy cover density, litter cover, and a higher number of fallen logs (Hannibal et al. 2020). Other recent studies also report this species in the Cerrado Goiano (Hannibal et al. 2015, Oliveira et al. 2015), which appear to be common in the region.

In the analysis of five digestive tracts of R. macrurus; $80 \%$ arthropods were found, from the orders Arachnida, Coleoptera, Hymenoptera, Isoptera, and insect larvae; and in $100 \%$ of the treatments, parts of plants were recorded, in addition to seeds of Piperaceae (Claro \& Hannibal, unpublished data). Considering the arboreal habits of $R$. macrurus, in which $91 \%$ of the catches occurred in the understory (1.5 to 2 m; Hannibal et al. 2020), and the fact of feeding on arthropods (Claro and Hannibal, unpublished data), our two hypotheses about accidental capture could be plausible. Given the rarity of these records, to our knowledge, this study is the first report of this species in a mist-net in Brazil. We emphasize that the use of mist-net must be well planned, considering the place of capture, the distance between the camp and the capture stations, in addition to the time to review the nets to avoid accidental capture, damage, or death of animals. 


\section{ACKNOWLEDGMENTS}

The authors thank the Conservation Unit, FLONA for the availability of a study in the region. The researcher, MBS recognizes his scholarship from the Coordination for the Improvement of Higher Education Personnel (CAPES) and from the Brazilian Fund for Biodiversity (FUNBIO). The researcher, DMS also thanks to the National Council for Scientific and Technological Development (CNPq) for supporting the research grant (Process number 307652 / 2018-1).

\section{REFERENCES}

Araújo WS, Porfirio-Júnior ED, Francener A, Hall CF. 2012. Composição florística e estrutura fitossociológica de áreas de campo sujo e cerrado sentido restrito na Floresta Nacional de Silvânia, Goiás, Brasil. Insula Revista de Botânica 41:42-58.

Bergamini BAR, Bergamini LL, Santos BB, Araujo WS. 2017. Distribuição de galhas de insetos em habitats xéricos e mésicos da Floresta Nacional de Silvânia, Brasil. Iheringia. Série Zoologia, 107: e2017042. https:// doi.org/10.1590/1678-4766e2017042.

Bonvicino CR, Oliveira JA, D'Andrea PS. 2008. Guia dos Roedores do Brasil, com chaves para gêneros baseadas em caracteres externos. Rio de Janeiro: Centro Pan-Americano de Febre, Aftosa OPAS/OMS, p.58

Fernandez DA, Amarga AK. 2020. Accidental mistnet capture of Viverratan galunga Gray 1832 (Viverridae) in Del Carmen Watershed, Siargao Island, Philippines. Southeast Asia Vertebrate Records,2020:042-044.

Garcia PFJ. 1998. Inventory methods for bats: standards for components of British Columbia's Biodiversity № 20. Canadian Cataloguing in Publication Data.

Gosler A. 2004. Birds in the hand. In: Bird ecology and conservation: a handbook of techniques (Sutherland, WJ, Newton I, Green RE eds). Oxford University Press. https:/ / doi.org/10.1093/acprof:0so/9780198520863.001.0001

Hannibal W, Cunha NL, Figueiredo VV, Teresa FB, Ferreira VL. 2020. Traits reveal how habitat-quality gradients structure small mammal communities in a fragmented tropical landscape. Austral Ecology, 45: 79-88. https://doi.org/10.1111/aec.12831

Hannibal W, Figueiredo V, Claro WP, Carvalho AC, Cabral GP, Oliveira RF, Aquino HF, Viana FV, Silveiro TF, Silva Filho JJ. 2015. Mamíferos não voadores em fragmentos de Cerrado no sul do estado de Goiás, Brasil. Boletim da Sociedade Brasileira de Mastozoologia, 74:103

Low SH. 1957. Banding with mist nets. A Journal of Ornithological Investigation, Maryland, 28(3):115128.

MMA. 2021. Ministério do Meio Ambiente - Instituto Chico Mendes de Conservação da Biodiversidade. Available in: https://www.icmbio.gov.br/portal/unidadesdeconservacao/biomasbrasileiros/cerrado/unidades-de-conservacao-cerrado/2077-flona-de-silvania. Accessed on 01, April 2021.

Sykes Jr PW. 1989. A Technique to Prevent Capturing Birds in Unattended, Furled Mist Nets. North American Bird Bander. 14: 45-46.

Tribe CJ. 2015. Genus Rhipidomys Tschudi, 1945. In: Patton JL, Pardiñas UFJ, D`Elía G (Eds) Mammal of South America, volume 2 - Rodents. Chicago and London: The University of Chicago Press, 583-617. 
Oliveira LM, Mello JPL, Matta SLP, Melo FR, Melo FCSA. 2015. Morfometria do compartimento intertubular dos testículos de roedores silvestres Necromys lasiurus e Rhipidomys macrurus (Cricetidae: sigmodontinae) capturados em área de Cerrado do Sudoeste de Goiás. Enciclopédia Biosfera, Centro Científico Conhecer - Goiânia, 11:2319.

Paglia AP, Fonseca GAB, Rylands AB, Hermann G, Aguiar LMS, Chiarello AG, Leite YLR, Costa LP, Siciliano S, Kierulff MCM, Mendes AL, Tavares VC, Mittermeier RA, Patton JL.2012. Lista anotada dos mamíferos do Brasil. 2a ed. OccasionalPaper, no - 6. Conservation International.

Peracchi AL, Nogueira MR. 2010. Métodos de captura de quirópteros em áreas silvestres. Técnicas de Estudos Aplicadas aos Mamíferos Silvestres Brasileiros. Congresso Brasileiro de Zoologia, Belém, Pará. USEB.

Editor: Diego J. Lizcano

Received 2021-01-22

Revised 2020-02-10

Accepted 2021-04-06

Published 2021-05-06 